\title{
PENERAPAN MODEL PROBLEM BASED LEARNING (PBL) UNTUK MENINGKATKAN PEMAHAMAN KONSEP PERUBAHAN SUHU DAN WUJUD BENDA PADA SISWA KELAS VC SDN 36 KENDARI
}

\author{
Yurindah ${ }^{1)}$, Amiruddin. $\mathrm{B}^{1)}$, Rimba Hamid ${ }^{1)}$ \\ ${ }^{1)}$ Jurusan Pendidikan Guru Sekolah Dasar \\ FKIP Universitas Halu Oleo \\ Email: yurindahpgsd061@gmail.com, amiruddin.b@uho.ac.id, rimbahamid@uho.ac.id
}

\begin{abstract}
Abstrak: Penelitian ini bertujuan untuk mengetahui peningkatan pemahaman siswa tentang konsep perubahan suhu dan wujud benda di kelas Vc SDN 36 Kendari melalui penerapan model Problem Based Learning (PBL). Jenis penelitian ini adalah Penelitian Tindakan Kelas (PTK) yang dilaksanakan dalam dua siklus. Setiap siklus melalui empat tahapan yaitu perencanaan, pelaksanaan tindakan, observasi dan refleksi. Subjek penelitian adalah siswa yang aktif dan terdaftar pada semester genap tahun ajaran 2019/2020 kelas Vc SDN 36 Kendari, dengan jumlah siswa 27 orang. Teknik pengumpulan data menggunakan observasi dan tes kemampuan pemahaman konsep. Teknik analisis data menggunakan analisisis deskriptif kualitatif dan kuantitatif. Hasil penelitian menunjukkan adanya peningkatan pemahaman konsep dari siklus I ke siklus II, dengan persentase ketuntasan 48,14\% dengan rata-rata 63,7 pada siklus I, menjadi 77,78\% dengan rata-rata 77,51 pada siklus II, dengan demikian penerapan model Problem Based Learning (PBL) dapat meningkatkan pemahaman siswa tentang konsep perubahan suhu dan wujud benda di kelas Vc SDN 36 Kendari.
\end{abstract}

Kata Kunci: Problem Based Learning; Pemahaman Konsep.

\section{APPLICATION OF THE PROBLEM BASED LEARNING (PBL) MODEL TO IMPROVE THE UNDERSTANDING OF THE CONCEPT OF TEMPERATURE CHANGES AND OBJECTIVES IN VC CLASS STUDENTS OF SDN 36 KENDARI}

\begin{abstract}
This research aims to determine the increase students' understanding of the concept of change in temperature and form of objects in class Vc SDN 36 Kendari through the application of Problem Based Learning (PBL). This type of research is a classroom action research (CAR), which is carried out in two cycles, each cycle going through four stage planning, implementing action, observations, and reflection. Subject of research is an active student and enrolled in the second semester of the academic year 2019/2020 class Vc SDN 36 Kendari, with the number of students to 27 people. Data collection techniques using observations and test understanding of concepts. Data analysis techniques using qualitative and quantitative descriptive analysis. The results showed an increased understanding of the concept of the first cycle to the second cycle, the percentage of completeness $48,14 \%$ with an average of 63.7 in the first cycle to 77,78\% with an average of 77,51 in the second cycle, thus the use of Problem Based Learning models can improve students' understanding of the concept of changes in temperature and form of objects.
\end{abstract}

Keywords: Problem Based Learning; Concept Understanding 


\section{Pendahuluan}

Keberhasilan pendidikan tidak lepas dari proses belajar mengajar, yang di dalamnya meliputi beberapa komponen yang saling terkait, antara lain: guru (pendidik), siswa (peserta didik), materi (bahan), media (alat/sarana), dan metode atau pola penyampaian bahan ajar. Proses belajar mengajar akan terorganisir dengan baik apabila terdapat kesiapan siswa dengan segala potensinya yang meliputi aspek kognitif, afektif dan psikomotorik. Selain itu, guru yang mampu menciptakan suasana belajar yang mendukung pemberdayaan seluruh potensi yang dimiliki siswa. Pembelajaran di bangku sekolah dibagi dalam beberapa jenjang yang dimulai dari pendidikan dasar sampai pendidikan tinggi. Berdasarkan Undang-Undang No. 20 Tahun 2003 tentang Sistem Pendidikan Nasional (pasal 17 ayat 1), " Pendidikan dasar merupakan jenjang pendidikan yang melandasi jenjang pendidikan menengah" (Triyana, Manuaba, \& Putra, 2014, p. 2). Oleh karena itu guru Sekolah Dasar (SD) hendaknya mampu melaksanakan pembelajaran yang bermakna agar siswa mempunyai bekal pengetahuan yang kuat untuk jenjang selanjutnya. Pembelajaran di SD merupakan pondasi yang kokoh untuk dapat memasuki jenjang pendidikan yang lebih tinggi dan juga untuk menghadapi tantangan perkembangan Ilmu Pengetahuan dan Teknologi (IPTEK).

Perkembangan Ilmu Pengetahuan dan Teknologi menuntut untuk mengembangkan pemikiran dan mengenal lingkungan alam, hal ini dapat dilakukan melalui pembelajaran di Sekolah Dasar, salah satunya dengan mempelajari Ilmu Pengatahuan Alam (IPA). Menurut Triyanto (Widhiatma, 2017, p. 448) IPA adalah suatu kumpulan yang sistematis, penerapannya secara umum terbatas pada gejala-gejala alam, lahir dan berkembang melalui metode ilmiah seperti observasi dan eksperimen serta menuntun sikap ilmiah seperti rasa ingin tahu, terbuka, jujur dan sebagainya. Dalam kehidupan sehari-hari pembelajaran IPA mempelajari tentang gejala-gejala alam yang berlangsung pada lingkungan sehari-hari. Oleh sebab itu pembelajaran IPA dilakukan sejak Sekolah Dasar. Hal tersebut bertujuan untuk membekali peserta didik agar mampu berpikir logis, analitis, sistematis, kritis dan kreatif serta memiliki kemampuan kerjasama.

Melalui pembelajaran IPA diharapkan para siswa akan memperoleh pengalaman dalam bentuk kemampuan untuk bernalar induktif dengan berbagai konsep dan prinsip IPA. Kemampuan yang diperolehnya itu diharapkan dapat digunakan untuk mengungkap fenomena-fenomena alam dalam kehidupan sehari-hari, menerapkan prinsip-prinsip dari IPA dengan teknologi, mengembangkan kebiasaan dan sikap ilmiah untuk menemukan dan meningkatkan pemahaman konsep siswa. Pemahaman konsep memiliki peranan penting dalam proses belajar mengajar dan merupakan dasar dalam mencapai hasil belajar. Menurut Rosser (Hamdani, Kurniati, \& Sakti, 2012, p. 82) konsep adalah suatu abstraksi yang mewakili satu kelas objek-objek, kejadian-kejadian, atau hubungan-hubungan yang mempunyai atributatribut yang sama, untuk menanamkan suatu konsep dalam pelajaran, seorang guru perlu mengajarkannya dalam konteks nyata dengan mengaitkannya terhadap lingkungan sekitar. Hal ini akan mampu mengembangkan kemampuan berpikir kritis siswa dan meningkatkan pemahaman konsepnya terhadap materi yang diajarkan.

Berdasarkan hasil wawancara dengan guru kelas Vc di SDN 36 Kendari yaitu Ibu Binti, S.Pd, pada hari Rabu, 27 November 2019 diperoleh informasi bahwa pemahaman konsep siswa dalam pembelajaran IPA terkhusus materi Perubahan Suhu dan Wujud Benda masih tergolong rendah. Berdasarkan dari dokumentasi hasil belajar siswa ditemukan bahwa masih banyak siswa yang belum mencapai KBM, dimana dari data yang diperoleh pada tahun 
ajaran 2018/2019 pada kelas Vc yang berjumlah 30 siswa hanya 14 siswa atau 46,67\% yang memenuhi KBM yang ditetapkan yaitu 70 .

Berdasarkan hasil observasi di kelas Vc SDN 36 Kendari yang dilakukan oleh peneliti pada tanggal 27-29 November 2019, memperlihatkan bahwa guru masih menggunakan pembelajaran ceramah dan pemberian tugas, guru tidak menggunakan model pembelajaran yang inovatif. Siswa kurang dilibatkan sepenuhnya dalam pembelajaran dan tidak dilatih untuk menggali dan mengolah informasi serta memecahkan masalah. Siswa juga kurang dilatih untuk mengkontruksikan dan menemukan sendiri konsep yang ada. Informasi tentang konsep-konsep IPA hanya didapat siswa melalui penjelasan dari guru dan satu sumber buku cetak, sehingga ini berdampak pada pemahaman konsep siswa terhadap materi yang diajarkan.

Masalah mengenai proses pembelajaran yang menyebabkan pemahaman konsep siswa yang rendah membutuhkan pemecahan agar tidak terjadi berkelanjutan. Pemahaman konsep siswa yang rendah akan berdampak pada hasil belajar yang rendah pula. Siswa yang tidak paham dengan konsep yang diajarkan akan menghambat proses belajar dan tidak tercapainya tujuan pembelajaran, sehingga pemahaman konsep siswa perlu ditingkatkan. Guru juga hanya menilai siswa hanya berdasarkan ranah kognitif. Selain itu, aktivitas belajar dalam proses pembelajaran sangat menentukan hasil belajar siswa. Seharusnya siswa dituntut untuk aktif dalam proses pembelajaran sehingga siswa mampu mengembangkan potensi dirinya terutama dalam memahami konsep-konsep IPA. Menurut Astawan (Widiawati, Pudjawan, \& Margunayasa, 2015, pp. 2-3) siswa di Sekolah Dasar cenderung tertarik dengan masalahmasalah kecil, baik masalah buatan maupun masalah yang langsung ada di lingkungan sekitanya. Permasalahan tersebut akan melatih siswa untuk dapat berpikir kritis dan objektif dalam memecahkan masalah yang dihadapinya. Oleh karena itu, pelajaran IPA di Sekolah Dasar harus dilakukan dengan kegiatan yang menarik seperti penyelidikan sederhana, diskusi dan pengamatan secara langsung di lingkungan sekitar. Pembelajaran dengan menerapkan kegiatan tersebut akan lebih menarik perhatian siswa dan mampu meningkatkan rasa ingin tahu yang dimiliki siswa sehingga akan lebih meningkatkan konsentrasi siswa dalam mengikuti pembelajaran. Hal tersebut akan semakin memudahkan siswa dalam memahami konsep yang akan ditanamkan oleh guru. Konsep yang langsung diperoleh dari hasil berpikir kritis siswa dengan mengkonstruksi dari lingkungan sekitar ini akan lebih berkesan dan bertahan lebih lama, serta akan menjadi dasar yang baik bagi siswa untuk mampu mempelajari konsep lainnya dan meningkatkan pemahamannya terhadap materi yang sedang dipelajari.

Salah satu terobosan yang dapat digunakan untuk mengatasi permasalahan tersebut adalah menggunakan model pembelajaran yang berkaitan dengan kemampuan pemahaman konsep dan melatih kemampuan berpikir kritis, salah satunya adalah dengan menerapkan model Problem Based Learning (PBL). Menurut Ackai (Ejin, 2016, p. 66) didasarkan pada teori belajar konstruktivis. Model PBL merupakan salah satu contoh model pembelajaran terbaik untuk pembelajaran konstruktivis. Menurut Taşkesenligil, Şenocak \& Sözbilir (Kartal \& Bakaç, 2014, p.111) proper learning environments should be created for students where they can study and invent their scientific knowledge as scientists. Thus the student, without the need to memorize knowledge, will gain the ability to conceptualize learning. One of the approaches targeting learning through own experience and discovering knowledge is Problem Based Learning (PBL).

Menurut Shoimin (Fravitasari, Harjono, \& Airlanda, 2018, p. 158) Problem Based Learning merupakan model pembelajaran yang mampu melatih dan meningkatkan 


\section{Jurnal Ilmiah Pembelajaran Sekolah Dasar \\ Volume 2 Nomor 1 - Februari 2020, e-ISSN 2656-0402 \\ Available online at:http://ojs.uho.ac.id/index.php/jipsd}

kemampuan untuk memecahkan masalah yang berpusat pada masalah nyata dari kehidupan yang konkret. Model PBL juga mampu mengembangkan aktivitas ilmiah siswa melalui diskusi kelompok. Model PBL mengajak siswa agar mampu melatih kemampuan siswa dalam memecahkan masalah sehingga dapat meningkatkan pembelajaran yang efektif. Sejalan dengan pendapat tersebut menurut Suyatno (Rini, 2015, p. 104) model Pembelajaran Berdasarkan Masalah adalah proses pembelajaran yang titik awal pembelajaran dimulai berdasarkan masalah dalam kehidupan nyata siswa dirangsang untuk mempelajari masalah berdasarkan pengetahuan dan pengalaman telah mereka miliki sebelumnya (prior knowledge) untuk membentuk pengetahuan dan pengalaman baru, dengan pembelajaran yang berkaitan langsung dengan kehidupan nyata siswa, maka siswa dapat memahami suatu masalah dalam kehidupan sehari-hari untuk menyelesaikan masalah yang ada.

Menurut Shoimin (2017, p. 132) kelebihan dari model Problem Based Learning adalah: (1)Siswa didorong untuk memiliki kemampuan memecahkan masalah dalam situasi nyata. (2)Siswa memiliki kemampuan untuk membangun pengetahuanya sendiri melalui aktivitas belajar. (3) Pembelajaran berfokus pada masalah sehingga materi yang tidak ada hubunganya tidak perlu dipelajari oleh siswa hal ini mengurangi beban siswa dengan menghafal atau menyimpan informasi. (4)Terjadi aktivitas ilmiah pada siswa melalui kerja kelompok.(5) Siswa terbiasa menggunakan sumber-sumber pengetahuan, baik perpustakaan, internet, wawancara dan observasi. (6) Siswa memiliki kemampuan untuk menilai kemajuan belajarnya sendiri. (7) Siswa memiliki kemampuan untuk melakukan komunikasi ilmiah dalam kegiatan diskusi atau presentasi hasil pekerjaan mereka. (8) Kesulitan belajar siswa secara individual dapat diatasi melalui kerja kelompok dalam bentuk peer teaching.

Berdasarkan uraian di atas, masalah dalam penelitian ini adalah "Apakah penerapan model Problem Based Learning (PBL) dapat peningkatan pemahaman konsep Perubahan Suhu dan Wujud Benda pada siswa kelas Vc SDN 36 Kendari”.

\section{Metode Penelitian}

Jenis penelitian ini adalah penelitian tindakan kelas (PTK). Penelitian tindakan kelas adalah penelitian yang dilakukan oleh pendidik di dalam kelasnya melalui refleksi diri. Tujuanya adalah untuk memperbaiki kinerjanya sebagai pendidik, sehingga hasil belajar peserta didik menjadi meningkat dan secara sistem, mutu pendidikan pada satuan pendidikan juga meningkat (Tampubolon, 2013, p. 19). Pengertian lain dari penelitian tindakan kelas menurut Paidi (Kurniasih \& Sani, 2014, p. 2) adalah suatu kegiatan penelitian yang berkonteks kelas yang dilaksanakan untuk memecahkan masalah-masakah pembelajaran yang dihadapi oleh guru, memperbaiki mutu dan hasil pembelajaran dan mencobakan hal-hal baru dalam pembelajaran demi peningkatan mutu dan hasil pembelajaran. Penelitian tindakan kelas dapat dilakukan secara individu dan kolaboratif. Penelitian ini dilaksanakan di SD Negeri 36 Kendari yang terletak di Jl. Malik V No.10, Korumba, Kecamatan Mandonga, Kota Kendari, Sulawesi Tenggara, semester genap Tahun ajaran 2019/2020. Subjek dalam penelitian ini adalah siswa kelas Vc SD Negeri 36 Kendari yang terdaftar dan aktif pada semester genap Tahun ajaran 2019/2020 sebanyak 27 orang siswa yang terdiri dari 10 orang laki-laki dan 17 orang perempuan. Fakto-faktor yang diteliti pada penelitian ini adalah faktor guru, faktor siswa dan faktor pemahaman konsep.

Penelitian Tindakan Kelas ini dilaksanakan dalam dua siklus. Adapun prosedur penelitian ini mengikuti model desain Penelitian Tindakan Kelas Arikunto yang terdiri dari empat tahap meliputi: (1) Perencanaan, (2) Pelaksanaan Tindakan, (3) Observasi dan (4) 


\section{Jurnal Ilmiah Pembelajaran Sekolah Dasar \\ Volume 2 Nomor 1 - Februari 2020, e-ISSN 2656-0402 \\ Available online at:http://ojs.uho.ac.id/index.php/jipsd}

Refleksi dalam setiap siklus Arikunto (2015, p. 42). Jenis data dalam penelitian ini yaitu data kualitatif dan data kuantitatif. Data kualitatif diperoleh melalui observasi, menggunakan lembar observasi sedangkan data kuantitatif diperoleh melalui tes setiap akhir siklus tindakan. Analisis data yang digunakan dalam penelitian ini terbagi dua yaitu analisis kualitatif dan analisis kuantitatif. Data kualitatif akan dianalisis secara deskriptif kualitatif berdasarkan observasi yang telah dilakukan. Sedangkan data kuantitatif dianalisis secara deskriptif kuantitatif berdasarkan hasil tes pada setiap akhir siklus tindakan.

\section{Hasil Penelitian}

\section{Aktivitas Mengajar Guru}

Aktivitas mengajar guru selama proses pembelajaran dengan menggunakan model Problem Based Learning (PBL) siklus I dan siklus II dapat dilihat pada Tabel berikut ini.

Tabel 1. Pengamatan Aktivitas Mengajar Guru Siklus I dan Siklus II

\begin{tabular}{llcccc}
\hline \multirow{2}{*}{ No } & \multirow{2}{*}{ Uraian } & \multicolumn{2}{c}{ Siklus I } & \multicolumn{2}{c}{ Siklus II } \\
\cline { 3 - 6 } & & Pertemuan 1 & Pertemuan 2 & Pertemuan 1 & Pertemuan 2 \\
\hline 1. & Skor perolehan & 48 & 51 & 61 & 63 \\
\hline 2. & Skor total & 64 & 64 & 64 & 64 \\
\hline 3. & Persentase (\%) & 75 & 79,68 & 95,31 & 98,43 \\
\hline 4 & Rata-rata & & 77,34 & & 96,87 \\
\hline
\end{tabular}

Berdasarkan Tabel 1, terlihat bahwa persentase aktivitas mengajar guru siklus I yang dilakukan sebanyak dua kali pertemuan diperoleh hasil yakni pertemuan pertama sebesar $75 \%$ dan pertemuan kedua $79,68 \%$ sehingga rata-rata dari kedua pertemuan tersebut sebesar 77,34\%. Aktivitas mengajar guru pada siklus II mengalami penigkatan dari siklus sebelumnya, yakni pertemuan pertama sebesar $95,31 \%$ dan pertemuan kedua 98,43\% sehingga rata-rata dari kedua pertemuan tersebut sebesar $96,87 \%$.

\section{Aktivitas Belajar Siswa}

Aktivitas belajar siswa selama proses pembelajaran dengan menggunakan model Problem Based Learning (PBL) siklus I dan siklus II dapat dilihat pada Tabel berikut ini. Tabel 2. Hasil Pengamatan Aktivitas Belajar Kelompok siswa Siklus I

\begin{tabular}{|c|c|c|c|c|c|c|c|c|c|c|c|c|c|}
\hline \multirow{3}{*}{ No. } & \multirow{3}{*}{ Uraian } & \multicolumn{12}{|c|}{ Hasil Pengamatan Siklus I } \\
\hline & & \multicolumn{6}{|c|}{ Pertemuan 1/Perkelompok } & \multicolumn{6}{|c|}{ Pertemuan 2/Perkelompok } \\
\hline & & K1 & $\mathrm{K} 2$ & K3 & K4 & K5 & K6 & K1 & $\mathrm{K} 2$ & K3 & K4 & K5 & K6 \\
\hline 1. & Skor Perolehan & 35 & 31 & 27 & 26 & 28 & 24 & 36 & 34 & 28 & 30 & 31 & 27 \\
\hline 2. & Skor total & & & 44 & & & & & & 44 & & & \\
\hline 3. & Persentase & $\begin{array}{l}79, \\
55\end{array}$ & $\begin{array}{l}70, \\
45\end{array}$ & $\begin{array}{l}61, \\
36\end{array}$ & $\begin{array}{l}59 \\
09\end{array}$ & $\begin{array}{l}63, \\
64\end{array}$ & $\begin{array}{l}54, \\
55\end{array}$ & $\begin{array}{l}81, \\
82\end{array}$ & $\begin{array}{l}77, \\
27\end{array}$ & $\begin{array}{l}63, \\
64\end{array}$ & $\begin{array}{c}68, \\
18\end{array}$ & $\begin{array}{l}70, \\
45\end{array}$ & $\begin{array}{l}61, \\
36\end{array}$ \\
\hline 4. & Rata-rata & \multicolumn{6}{|c|}{64,77} & \multicolumn{6}{|c|}{70,45} \\
\hline
\end{tabular}


Tabel 3. Hasil Pengamatan Aktivitas Belajar Kelompok siswa Siklus II

\begin{tabular}{|c|c|c|c|c|c|c|c|c|c|c|c|c|c|}
\hline \multirow{3}{*}{ No. } & \multirow{3}{*}{ Uraian } & \multicolumn{12}{|c|}{ Hasil Pengamatan Siklus II } \\
\hline & & \multicolumn{6}{|c|}{ Pertemuan 1/Perkelompok } & \multicolumn{6}{|c|}{ Pertemuan 2/Perkelompok } \\
\hline & & K1 & $\mathrm{K} 2$ & K3 & K4 & K5 & K6 & K1 & $\mathrm{K} 2$ & K3 & K4 & K5 & K6 \\
\hline 1. & Skor Perolehan & 42 & 39 & 38 & 36 & 39 & 34 & 43 & 42 & 39 & 39 & 42 & 36 \\
\hline 2. & Skor total & \multicolumn{6}{|c|}{44} & \multicolumn{6}{|c|}{44} \\
\hline 3. & Persentase & $\begin{array}{r}95, \\
45 \\
\end{array}$ & $\begin{array}{r}88, \\
64 \\
\end{array}$ & $\begin{array}{l}86, \\
36 \\
\end{array}$ & $\begin{array}{l}81, \\
82\end{array}$ & $\begin{array}{r}88, \\
64 \\
\end{array}$ & $\begin{array}{l}77, \\
27 \\
\end{array}$ & $\begin{array}{l}97, \\
73 \\
\end{array}$ & $\begin{array}{r}95, \\
45 \\
\end{array}$ & $\begin{array}{c}88, \\
64\end{array}$ & $\begin{array}{l}88, \\
64\end{array}$ & $\begin{array}{l}95, \\
45 \\
\end{array}$ & $\begin{array}{l}81, \\
82 \\
\end{array}$ \\
\hline
\end{tabular}

Berdasarkan Tabel 2 dan Tabel 3, terlihat bahwa persentase aktivitas kelompok siswa pada aktivitas belajar kelompok pada siklus I pertemuan 1 dengan rata-rata 64,77 dan pertemuan 2 dengan rata-rata 70,45. Sedangkan pada siklus II meningkat yaitu pertemuan 1 dengan rata-rata 86,36 dan pertemuan 2 dengan rata-rata 91,29.

\section{Hasil Tes Pemahaman Konsep Siswa}

Hasil tes pemahaman konsep siswa setelah diterapkan model Problem Based Learning (PBL) dalam proses pembelajaran, pada siklus siklus I dan siklus II dapat dilihat pada Tabel berikut ini.

Tabel 4. Analsis Hasil tes pemahaman konsep

\begin{tabular}{clccc}
\hline No & \multicolumn{1}{c}{ Hasil Tes Pemahaman Konsep } & Jumlah Siswa & Persentase (\%) \\
\hline 1. & Siklus 1 & 13 & \\
\cline { 2 - 5 } & a. $\quad$ Tuntas & 14 & 48,14 \\
\cline { 2 - 5 } & b. $\quad$ Tidak tuntas & & 51,86 \\
\hline 2. & Siklus II & 21 & 77,78 \\
\cline { 2 - 4 } & a. $\quad$ Tuntas & 6 & 22,22 \\
\cline { 2 - 4 } & b. $\quad$ Tidak tuntas & & \\
\hline
\end{tabular}

Berdasarkan Tabel 4, hasil analisis penelitian pada siklus I dari 27 orang siswa, yang tuntas sebanyak 13 siswa dengan persentase ketuntasan sebesar 48,14\%, dan yang tidak tuntas sebanyak 14 siswa dengan persentase sebesar 51,86\% dengan nilai rata-rata hasil belajar siswa adalah 63,7\%. Sedangkan pada siklus II menunjukkan bahwa hasil belajar siswa terhadap materi pembelajaran mengalami peningkatan dari 27 siswa yang tuntas sebanyak 21 siswa dengan persentase ketuntasan sebesar 77,78\%, dan yang tidak tuntas sebanyak 6 siswa dengan persentase sebesar $22,22 \%$.

\section{Pembahasan}

\section{Aktivitas Mengajar Guru}

Aktivitas mengajar guru dalam penelitian ini diketahui melalui hasil observasi pada setiap siklus tindakan disetiap pembelajaran. Hasil observasi siklus I menunjukan bahwa ratarata aktivitas mengajar guru pada siklus I adalah 77,34\%. Hasil persentase aktivitas guru pada 


\section{Jurnal Ilmiah Pembelajaran Sekolah Dasar \\ Volume 2 Nomor 1 - Februari 2020, e-ISSN 2656-0402 \\ Available online at:http://ojs.uho.ac.id/index.php/jipsd}

siklus I sudah termasuk baik, namun masih perlu ditingkatkan lagi, karena dengan persentase tersebut berarti masih ada kegiatan pembelajaran dengan menerapkan model Problem Based Learning (PBL) yang masih belum terlaksana dengan baik.

Melihat dari kekurangan yang masih ada serta hasil pemahaman konsep siswa belum mencapai indikator keberhasilan yang telah ditetapkan, maka dilaksanakan refleksi dan perbaikan untuk melaksanakan tindakan pada siklus selanjutnya yaitu siklus II. Hasil refleksi dijadikan acuan dalam melaksanakan siklus II. Proses pembelajaran yang baik akan berpengaruh pada peningkatan persentase terlaksana seluruh kegiatan pembelajaran.

Berdasarkan hasil analisis dan refleksi tersebut, guru melakukan perbaikan-perbaikan untuk diterapkan di siklus II. Grafik kenaikan aktivitas mengajar guru pada siklus I dan siklus II dapat dilihat pada Gambar berikut ini:

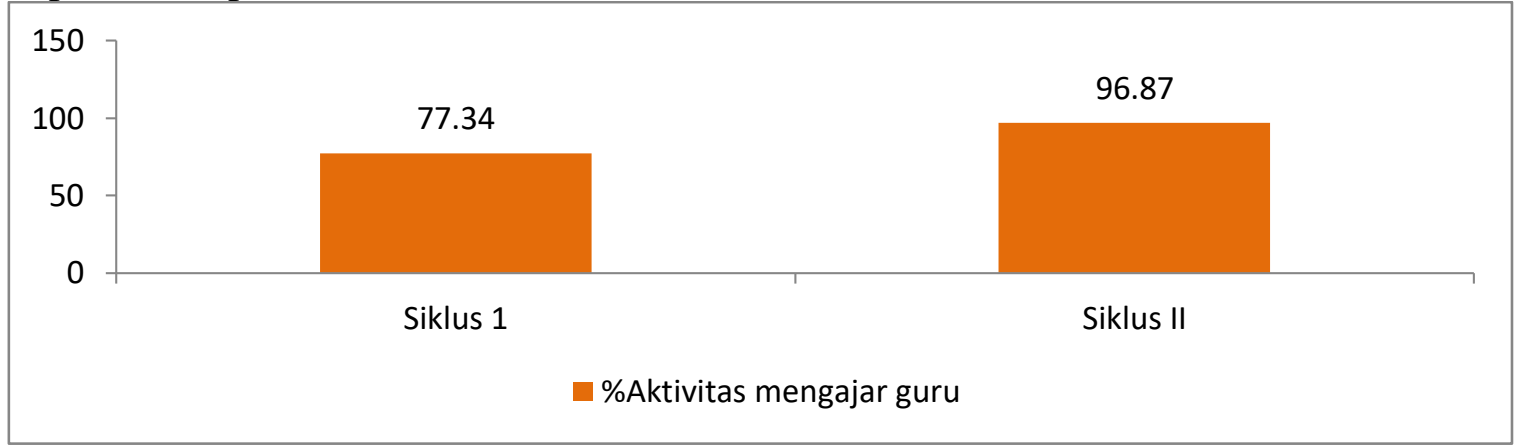

Gambar 1. Persentase Peningkatan Aktivitas Mengajar Guru Siklus I dan Siklus II

Berdasarkan Gambar 1, terlihat bahwa terjadi peningkatan aktivitas mengajar guru dari siklus I ke siklus II. Pada siklus II rata-rata aktivitas mengajar guru mengalami peningkatan yang siginifikan yaitu $96,87 \%$ dengan kategori sangat optimal. Aktivitas mengajar guru sudah mencapai standar indikator keberhasilan yang telah ditetapkan. Hasil ini menunjukkan bahwa guru telah melaksanakan kegiatan pembelajaran dengan sangat optimal. Penerapan model pembelajaran Problem Based Learning (PBL) menjadikan guru sebagai fasilitator atau mengarahkan siswa dalam proses pembelajaran. Dengan penerapan model pembelajaran Problem Based Learning (PBL) menjadikan siswa untuk berfikir kritis dan memiliki keterampilan dalam memecahkan masalah. Hal tersebut sesuai dengan Arends (Widhiatma, 2017) PBL tidak dirancang untuk membantu guru menyampaikan informasi dengan jumlah besar kepada siswa. PBL dirancang untuk membantu siswa mengembangkan keterampilan berpikir, keterampilan menyelasaikan masalah, dan keterampilan intelektual.

\section{Aktivitas Belajar Siswa}

Agar terjadi aktivitas ilmiah dan tukar pemikiran dalam usaha membangun pengetahuan secara kolaboratif, proses belajar mengajar dalam model Problem Based Learning (PBL) dilakukan dalam kelompok kecil, dalam penelitian ini, siswa dibagi dalam 6 kelompok. Setiap kelompok terdiri dari 4-5 orang. Pembentukan kelompok dilakukan secara heterogen. Hasil observasi aktivitas belajar siswa pada siklus I belum mencapai indikator keberhasilan dimana aktivitas belajar siswa dikatakan berhasil jika $\geq 75 \%$ siswa terlibat aktif dalam proses pembelajaran, rata-rata hasil belajar kelompok siswa pada Siklus I yaitu 67,61\% dengan kategori cukup aktif. 


\section{Jurnal Ilmiah Pembelajaran Sekolah Dasar \\ Volume 2 Nomor 1 - Februari 2020, e-ISSN 2656-0402 \\ Available online at:http://ojs.uho.ac.id/index.php/jipsd}

Berdasarkan hasil refleksi siklus I, hal-hal yang perlu ditingkatkan yaitu pada tahap penyelidikan secara berkelompok masih banyak siswa yang belum bisa bekerjasama dengan kelompoknya serta kurang serius melakukan penyelidikan, dalam kegiatan mengembangkan dan menyajikan hasil karya beberapa siswa kurang terlibat dalam diskusi kelompok karna merasa sudah dikerjakan oleh siswa yang dianggap pintar dan juga ketika kegiatan menyajikan hasil karya/hasil diskusi siswa masih malu-malu dan kurang percaya diri, keberanian siswa dalam bertanya juga masih kurang. Kelemahan inilah yang akan ditingkatkan pada siklus II.

Berdasarkan hasil observasi tersebut maka dilakukan refleksi antara guru dan peneliti untuk melihat serta melakukan perbaikan-perbaikan yang dapat dilakukan pada siklus II. Setelah melakukan refleksi serta perbaikan-perbaikan, diperoleh skor rata-rata aktivitas belajar kelompok siswa pada siklus II yaitu 88,82\% dengan kategori sangat aktif. Grafik kenaikan aktivitas belajar siswa pada siklus I dan siklus II dapat dilihat pada Gambar berikut ini:

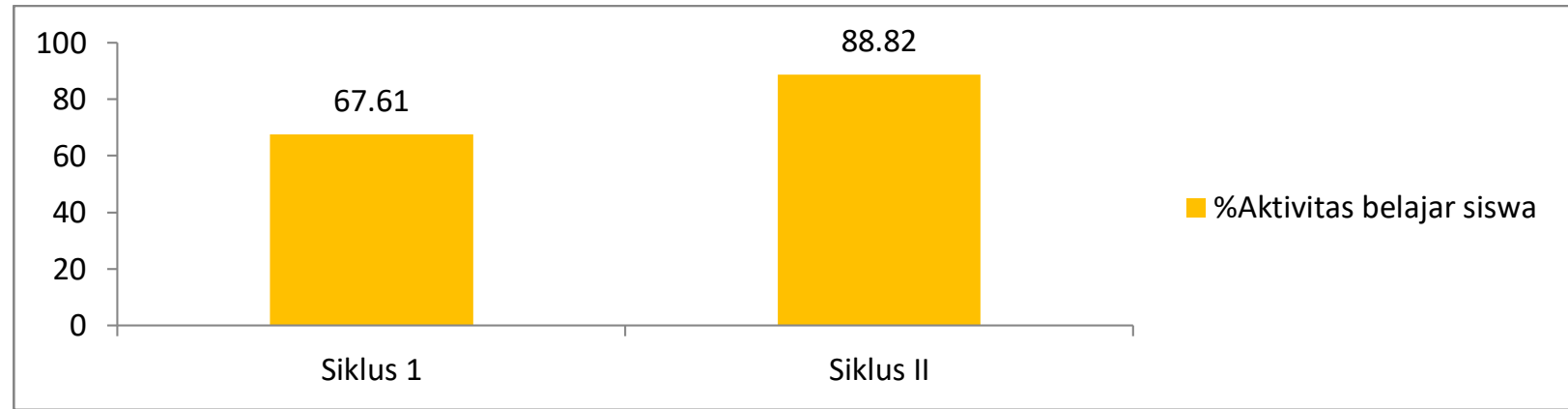

Gambar 2. Persentase Peningkatan Aktivitas Belajar Siswa Siklus I dan Siklus II

Berdasarkan Gambar 2, terlihat peningkatan aktivitas belajar siswa pada siklus I ke siklus II cukup signifikan. Penerapan model Problem Based Learning (PBL) memberikan perubahan yang positif dalam pembelajaran. Dampak positif tersebut terlihat dari pembelajaran yang dilakukan sudah tidak berpusat kepada guru. Temuan ini sesuai dengan pendapat Eka Cahya Prima (2011, p. 4) menyatakan bahwa ketika diterapkan PBL, terjadi perubahan pusat pembelajaran dari belajar berpusat pada guru kepada belajar berpusat pada siswa sehingga tercipta kondisi lingkungan belajar yang dapat membelajarkan siswa, dapat mendorong siswa belajar, atau memberi kesempatan kepada siswa untuk berperan aktif mengkonstruksi konsep-konsep yang dipelajarinya melalui keterampilan proses yang diperolehnya ketika melakukan kegiatan percobaan.

\section{Pemahaman Konsep Siswa}

Dari hasil analisis tes kemampuan pemahaman konsep siswa pada siklus I secara keseluruhan mencapai persentase ketuntasan 48,14\% dengan nilai rata-rata 63,7. Ketuntasan ini masih jauh dari target peneliti yaitu ketuntasan secara klasikal $\geq 75 \%$ siswa memperoleh nilai $\geq 70$. Melihat hasil refleksi pada siklus I yang belum mencapai indikator keberhasilan, maka penelitian ini dilanjutkan dengan melaksanakan tindakan pada siklus II, agar aktivitas dan nilai perolehan siswa dapat meningkat dan mencapai standar indikator yang telah ditetapkan, maka proses pembelajaran harus dibenahi dan ini artinya harus dilaksanakan siklus II. Perbaikan-perbaikan yang dilakukan pada siklus II, utamanya kinerja guru dalam memotivasi siswa, memfasilitasi serta membimbing siswa dalam proses pembelajaran, selain itu ketidak tuntasan siswa diakibatkan kurangnya perhatian serta keterlibatan siswa dalam proses pembelajaran. Setelah dilakukannya refleksi serta perbaikan-perbaikan antara guru dan 
peneliti, hasil tes pemahaman konsep siswa mengalami peningkatan. Pada siklus II perolehan nilai tes hasil belajar telah mencapai persentase ketuntasan sebesar 77,78\% dengan nilai ratarata 77,51. Hasil tersebut menandakan bahwa indikator keberhasilan penelitian yang ditetapkan telah tercapai dimana $\geq 75 \%$ mencapai Kriteria Belajar Minimal (KBM) yang ditetapkan sekolah yaitu 70. Dari hasil tersebut penelitian ini telah dianggap berhasil mencapai tergetnya dan menunjukkan bahwa dengan menerapkan model Problem Based Learning (PBL) dalam pembelajaran, maka model tersebut memiliki dampak positif dalam pembelajaran yaitu dapat meningkatkan pemahaman siswa mengenai konsep Perubahan Suhu dan Wujud Benda. Jumlah peningkatan dari siklus I ke siklus II sebesar 29,63\%. Untuk lebih jelasnya peningkatan pemahaman siswa dapat dilihat pada Gambar berikut ini:

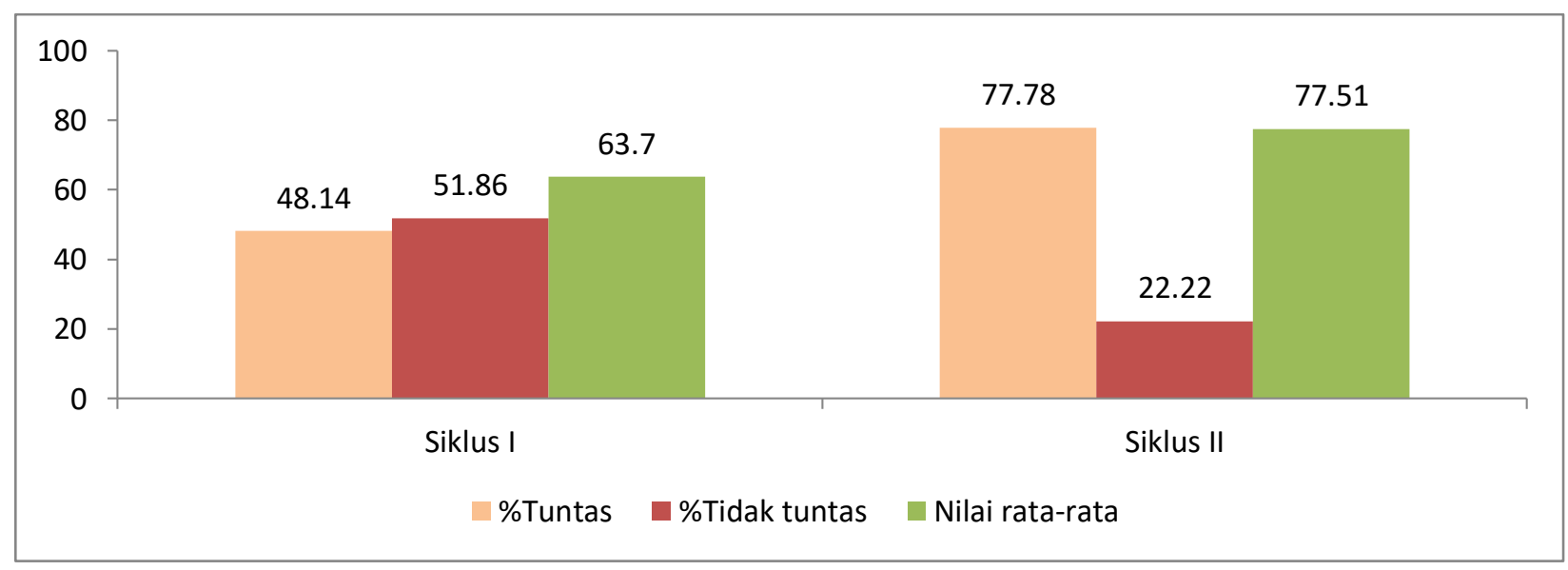

Gambar 3. Hasil Tes Pemahaman Konsep Siswa Siklus I dan Siklus II

Berdasarkan Gambar 3, terlihat bahwa terjadi peningkatan pemahaman konsep siswa pada siklus I ke siklus II. Peningkatan yang terjadi merupakan dampak dari perubahan aktivitas siswa dalam mengikuti proses pembelajaran, karna dalam sintaks Problem Based Learning (PBL) menekankan pembelajaran yang berpusat pada siswa dan konsep yang diperoleh berasal dari proses dalam menyelesaikan masalah, dengan diterapkannya model PBL akan mendorong siswa untuk melakukan kegitan proses pemecahan masalah yang akan membangun konsep yang dimilikinya. Sesuai dengan pendapat para ahli psikologi yang mengatakan bahwa anak-anak mudah memahami konsep-konsep yang rumit dan abstrak jika disertai dengan contoh-contoh konkret, contoh-contoh yang wajar sesuai dengan situasi dan kondisi yang dihadapi, dengan mempraktekkan sendiri upaya penemuan konsep melalui kegiatan penyelidikan, sehingga akan terbentuk penguasaan konsep yang utuh mengenai permasalahan yang dihadapinya. Temuan ini sejalan dengan pendapat yang dikemukakan oleh Sitiatava (Pawe, Chumdari, \& Mahfud, 2017, p. 5) bahwa pembelajaran dengan PBL membuat siswa lebih memahami konsep yang diajarkan lantaran ia menemukan sendiri konsep tersebut dan PBL dapat menumbuhkembangkan kemampuan kreativitas siswa, baik secara individual maupun kelompok, karena hampir disetiap langkah menuntut adanya keaktifan siswa.

Penelitian ini menerapkan model Problem Based Learning (PBL) untuk meningkatkan pemahaman konsep Perubahan Suhu dan Wujud Benda. Problem Based Learning (PBL) merupakan model pembelajaran yang dalam pelaksanaannya menuntut siswa untuk terlibat aktif dalam kegiatan pembelajaran dengan memecahkan masalah-masalah yang berkaitan dengan kehidupan sehari-hari siswa. Sehingga model Problem Based Learning 


\section{Jurnal Ilmiah Pembelajaran Sekolah Dasar \\ Volume 2 Nomor 1 - Februari 2020, e-ISSN 2656-0402 \\ Available online at:http://ojs.uho.ac.id/index.php/jipsd}

(PBL) dapat membantu siswa untuk lebih memahami konsep materi yang diajarkan. Sehingga dari uraian tersebut membuktikan bahwa dengan model Problem Based Learning (PBL) dapat meningkatkan aktivitas mengajar guru, aktivitas belajar siswa serta pemahaman konsep Perubahan Suhu dan Wujud Benda pada siswa kelas Vc SDN 36 Kendari. Hasil penelitian ini sesuai dengan penelitian yang dilakukan oleh Syahrojin Ejin (2016) yang berjudul "Pengaruh Model Problem Based Learning (PBL) terhadap Pemahaman Konsep dan Keterampilan Berpikir Kritis Siswa Kelas IV SDN Jambu Hilir Baluti 2 pada Mata Pelajaran Ilmu Pengetahuan Alam". Berdasarkan hasil penelitian menyimpulkan bahwa kemampuan pemahaman konsep siswa yang mendapatkan perlakuan dengan model pembelajaran Problem Based Learning (PBL) secara signifikan lebih baik dan lebih tinggi dibandingkan kelas Konvensional.

\section{Simpulan}

Berdasarkan analisis data dan pembahasan hasil penelitian, maka dapat disimpulkan sebagai berikut:

1. Aktivitas mengajar guru dalam proses pembelajaran IPA dengan menerapkan model Problem Based Learning (PBL) pada siklus I dengan rata-rata 77,34, meningkat pada siklus II dengan rata-rata 96,87.

2. Aktivitas belajar siswa dalam proses pembelajaran IPA dengan menerapkan model Problem Based Learning (PBL) pada siklus I dengan rata-rata 67,61, meningkat pada siklus II dengan rata-rata 88,82 .

3. Penerapan model Problem Based Learning (PBL) dapat meningkatkan pemahaman siswa tentang konsep Perubahan Suhu dan Wujud Benda di kelas Vc SDN 36 Kendari, pada siklus I dengan persentase ketuntasan 48,14\% dengan nilai rata-rata 63,38 meningkat pada siklus II mencapai persentase ketuntasan 77,78\% dengan nilai rata-rata 77,51.

\section{Daftar Pustaka}

Arikunto, S. (2015). Penelitian Tindakan Kelas. Jakarta: PT Bumi Aksara.

Ejin, S. (2016). Pengaruh Model Problem Based Learning (PBL) terhadap Pemahaman Konsep dan Keterampilan Berpikir Kritis Siswa Kelas IV SDN Jambu Hilir Baluti 2 pada Mata Pelajaran Ilmu Pengetahuan Alam. Jurnal Pendidikan, 1, 65-71. https://doi.org/10.26740/jp.v1n1.p6672

Eka Cahya Prima, I. K. (2011). Penerapan Model Pembelajaran Problem Based Learning Dengan Pendekatan Inkuiri Untuk Meningkatkan Ketrampilan Proses Sains dan Penguasaan Konsep Elastisitas pada Siswa SMA. Journal.Fmipa.Upi. https://doi.org/10.18269/jpmipa.v16i1.279

Fravitasari, A. F., Harjono, N., \& Airlanda, G. S. (2018). Penerapan Model Pembelajaran Problem Based Learning untuk Meningkatkan Proses dan Hasil Belajar Muatan IPA Tema 8 Sub Tema 1 Kelas 4. Journal for Lesson and Learning Studies, 1(3), 157-164. https://doi.org/10.23887/jlls.v1i3.15401

Hamdani, D., Kurniati, E., \& Sakti, I. (2012). Pengaruh Model Pembelajaran Generatif dengan Menggunakan Alat Peraga terhadap Pemahaman Konsep Cahaya Kelas VII Di SMP Negeri 7 Kota Bengkulu. Jurnal Exacta, X(1), 79-88. http://repository.unib.ac.id/id/eprint/6693 


\section{Jurnal Ilmiah Pembelajaran Sekolah Dasar \\ Volume 2 Nomor 1 - Februari 2020, e-ISSN 2656-0402 \\ Available online at:http://ojs.uho.ac.id/index.php/jipsd}

Kartal, A., \& Bakaç, M. (2014). The Effect of Problem Based Learning Approach on Conceptual Understanding in Teaching of Magnetism Topics. International Journal of Physics and Chemistry Education,6(September 2013), 110-122. http://www.ijpce.org/index.php/IJPCE/article/view/60

Kurniasih, I., \& Sani, B. (2014). Penelitian Tindakan Kelas. Jakarta: Kata pena.

Pawe, Y. E., Chumdari, \& Mahfud, H. (2017). Peningkatan Pemahaman Konsep Gaya Magnet melalui Model Pembelajaran PBL (Problem Based Leraning) pada Siswa Sekolah Dasar. Jurnal.Fkip.Uns.Ac.Id, 5(2).

Rini, R. (2015). Peningkatan Keterampilan Proses Saintifik dan Hasil Belajar Siswa Kelas 4 SDN Slungkep 02 Tema Peduli terhadap Makhluk Hidup Menggunakan Model Problem Based Learning. Scholaria, 5(1), 103-113. https://doi.org/10.24246/j.scholaria.2015.v5.i1.p103-113

Shoimin, A. (2017). 68 Model Pembelajaran Inovatif Dalam Kurikulum 2013. Yogyakarta: Ar-Ruzz Media.

Tampubolon, S. (2013). Penelitian Tindakan Kelas. Jakarta: Erlangga.

Triyana, I. N., Manuaba, I. B. S., \& Putra, M. (2014). Pengaruh Model Pembelajaran Berbasis Masalah (PBM) terhadap Hasil Belajar IPA Siswa Kelas V SD Gugus Iv Tampaksiring Tahun Pelajaran 2013 / 2014. Jurnal Mimbar PGSD Universitas Pendidikan Ganesha, 2(1). http://dx.doi.org/10.23887/jjpgsd.v2i1.3539

Widhiatma, Y. (2017). Penerapan Model Problem Based Learning untuk Meningkatkan Hasil Belajar IPA Siswa Kelas 4 SDN Kalinanas 01. E-Jurnalmitrapendidikan, 1, 447-459. http://ejurnalmitrapendidikan.com/index.php/e-jmp/article/view/85

Widiawati, N. P., Pudjawan, K., \& Margunayasa, I. G. (2015). Analisis Pemahaman Konsep Dalam Pelajaran IPA Pada Siswa Kelas IV SD di Gugus II Kecamatan Banjar. E-Journal PGSD Universitas Pendidikan Ganesha, 3. http://dx.doi.org/10.23887/jjpgsd.v3i1.5847 